\title{
MULTILATERAL DIPLOMACY IN THE NUCLEAR AGE *
}

\author{
AbBa EBan $\dagger$
}

Owen J. Roberts adorned the highest Court of your land at an eventful period in its development. His name is held in special reverence throughout the Commonwealth of Pennsylvania. I count it an honor to share some reflections with you in tribute to his memory and his achievements.

The list of my predecessors in this lecture series fills me with awe. Most of them have been men whose star shone brightly in the juridical traditions of their nations. Some of them have been eminent in international law-the law which the righteous do not need and which the wicked do not obey. I am no specialist in the juridical science. I am rescued from solitude in this series only by the participation in it some years ago of the Foreign Minister of Belgium, Mr. Paul Henri Spaak, who has, like all practicing diplomats, experienced the cold winds that blow up in the gap dividing aspiration from reality.

Mr. Spaak was the President of the General Assembly of the United Nations at its first session in 1946. That was an era in which hope ran high. In the glow of the nuclear explosion at Hiroshima it was hoped that a new and salutary prudence would govern international history. It seemed possible to organize a family of nations governed by a covenant of law and peace. And what seemed possible was patently necessary.

All historic experience proves that men behave wisely only when they have exhausted every other alternative. Since Adam and Eve tasted the apple in the Garden of Eden, man has never abstained from any folly of which he is inherently capable. But now the atomic terror appeared to close all the other alternatives. Henceforward it became obvious that in our generation a clear choice would be taken. Either mankind would abolish war or war would abolish mankind. In the light of this alternative, international relations have now become the central human enterprise. We cannot afford to live in a world of revolutionary science and conservative diplomacy. Our age calls for a searching reappraisal of diplomatic techniques.

* This article was presented orally as the Owen J. Roberts Memorial Lecture, delivered February 8, 1966, under the auspices of the Pennsylvania Chapter of the Order of the Coif and the University of Pennsylvania Law School.

$\dagger$ Minister for Foreign Affairs of Israel. 
Since the end of the Second War, the traditional diplomacy has declined in face of three new habits: summitry, public diplomacy and international debate.

\section{The "Summit" Concept}

The jet plane and telephone make it tempting for governments to confer at their highest level of responsibility. This creates a permanent hazard for ambassadors. Most of them look back with wistful yearning to the age when they were immune from persistent ministerial visitations. Thomas Jefferson, as President of the United States, once wrote the following memorandum to his Secretary of State: "We have not heard from our Ambassador in Spain for two years. If we do not hear from him this year, let us write him a letter." This splendid utterance reflects the leisured atmosphere of an age in which the title of "Ambassador Plenipotentiary" was more than a fiction. The history of the United States contains the most salient example of diplomatic agents taking momentous decisions on their own account. Robert Livingston and James Monroe were empowered to purchase New Orleans and West Florida for ten million dollars. They ended up by buying half a continent for fifteen million dollars-doubling the area of the United States and adding a tract of eight hundred twenty thousand square miles between the Mississippi and the Rocky Mountains. Most people would agree that this was a good real estate investment, even if the envoys exceeded their constitutional powers. Today they would have been able to make a telephone call to their Department which would have sternly instructed them not to waste money on extrabudgetary luxuries.

The argument against excessive summiteering is that it involves the prestige of the negotiating parties at a level on which compromise is most difficult. Moreover, heads of state are, by the nature of their office, prevented from undertaking the detailed, prolonged, careful exploration from which precise agreements emerge. They are a court of last resort. They cannot therefore launch tentative noncommittal ideas in a free play of intellectual initiative. This is probably why Philippe de Comines in the fifteenth century wrote: "Two great princes who wish to establish good personal relations should never meet each other face to face but ought to communicate through good and wise emissaries." More recently, Mr. Dean Rusk has written: "Summit diplomacy is to be approached with the wariness with which a prudent physician prescribes a habit-forming drug - a technique to be employed rarely and under the most exceptional circumstances, with rigorous safeguards against its becoming a debilitating or dangerous habit 
- The experienced diplomat will usually counsel against the direct confrontation of those with final authority."

The meagre results of spectacular summit meetings have borne out these warnings. On the other hand, the crisis of the Berlin blockade, the Japanese peace treaty, the Arab-Israel armistice agreements, the Austrian peace treaty, the arrangements for free passage in the Gulf of Aqaba and the nuclear test-ban treaty are contrary examples of agreements achieved by contact and negotiation at lower levels of hierarchy.

\section{Open Diplomacy}

Summitry is closely linked with publicity. The reticence and intimacy of classic diplomacy have fallen into disuse. It is a common liberal belief that a special nobility attaches to international relations if they are conducted in full public view. The idealism of the post-war decades reacts with suspicion to secret, bilateral discourse. The distrust of classic diplomatic practice was memorably expressed by Woodrow Wilson: "Open covenants openly arrived at, after which there shall be no private understanding of any kind but diplomacy shall proceed always frankly and in the public view."

The motive for the Wilsonian view had been formulated by its author some years before. He was reacting against transactions which imposed settlements on peoples without their consent. He was also obsessed by the urgent need to develop a sense of universal community. "The great things remaining to be done can only be done with the whole world as a stage and in cooperation with the universal forces of mankind." The word "stage" is significant. The dream of an open diplomacy conducted in a permanent public arena was not fulfilled after the First World War, when Wilson's hopes petered out in personal and international tragedy. But three decades later, on the morrow of the Second World War, the era of open covenants dawned. Diplomacy was thrown open to public scrutiny. Spectacular international gatherings became the routine of diplomatic intercourse. Publicity invaded the bilateral discourse as well. In many countries an ambassador cannot even call on a Foreign Minister without every single encounter becoming an immediate subject of announcement or speculation. The press and radio thus become active parties in the negotiation at every step. Seated on a stage with the whole world as their audience, the public diplomats speak to the world rather than to each other. Their primary aim is, in many cases, not so much to reach agreement, as to convince their own people of their austere and heroic inflexibility. 
Few democratic diplomats can shut their ears to the clamor of those requiring them to manifest an absolute rigidity. A British Premier and Foreign Secretary, Arthur James Balfour, is said to have discharged those lofty offices without ever reading a newspaper, and De Tocqueville wrote that "indifference to newspapers is the first quality of a diplomat." Today this is more easily said than done. It is certain that many honorable and viable agreements which would have commanded support once concluded have been smothered in their infancy by being prematurely exposed to a suspicious public glare at an early stage of their crystallization. Conference diplomacy is especially prone to the ills of publicity. Dag Hammarskjold expressed a plea "to give greater emphasis to the United Nations as an instrument for negotiation of settlements, as distinct from the mere debate of issues." The plea was vain. Debate, not negotiation, has monopolized the United Nations practice. Speeches are made not by delegate to delegate, but by each delegate to an invisible, pervasive audience outside the hall. Classic diplomacy, with its formal manners and measured words, with its atmosphere conducive to compromise and restraint, is under eclipse. De Tocqueville wrote that "in a democracy external decisions are only taken for internal reasons." This is much exaggerated, but the pressure of public opinion on every stage of the diplomatic process is likely to bring the exaggeration into the realm of truth.

\section{Multilateral Diplomacy}

After twenty years of intensive practice, there is room for a more reserved judgment on the utility of diplomacy by debate. I do not wish to formulate my reservation in unqualified terms. Parliamentary diplomacy responds to some of the realities of the nuclear world. For the first time in human history, mankind is joined in a common destiny of opportunity and danger. For centuries past, events occurring in one part of the world had no repercussion in others. Human experience was local and fragmented. Even cultural history was essentially provincial. It unfolded in water-tight compartments. The climactic era in the history of culture came in the sixth and fifth centuries before the present era. During that period, Buddha, Confucius and Zoroaster wrote and preached. Philosophy and drama reached their florescence in Athens. And the somber visions of Hebrew prophecy were uttered in Judaea. The astonishing thing is that the Hebrew prophets, the Greek dramatists and philosophers, Buddha, Zoroaster and Confucius lived, died and created in the same era without ever hearing of each other. There was no cross-fertilization of intellectual and spiritual influence. Similarly, the wars, political struggles and economic enter- 
prise of nations had little effect beyond their immediate scene. Today we live in the first era of global history. The main problems affecting the human situation cannot be relevantly discussed, still less solved, except on a planetary scale. It is hard to conceive of any event of significance taking place in one part of the globe without immediate repercussion across the entire human scene. There are issues which are everybody's business and which are, therefore, nobody's responsibility. In such a world a unitary framework of international relations corresponds to the authentic mutuality of human fate.

Every year, the heads of one hundred fifteen sovereign governments survey the state of their nations. But there is no authority with power to survey the state of the entire human family, in its full breadth and complexity.

What would a President of the World responsible for the human destiny have to report if he faced a universal Parliament in the year 1965 ?

1) Sixty per cent of the earth's land surface is arid or semi-arid and is only capable of supporting five per cent of the world's population.

2) The inhabitants of the earth now number three billion and at the present rate of increase, will number six billion at the end of the twentieth century. It took centuries to double the world's population. It will take only thirty-six years to double it again.

3) More than half of the world's present population suffer from varying degrees of malnutrition. The increase of food production is not keeping pace with population growth.

4) The expectation of life which reaches an average of seventy years in developing countries is as low as thirty in parts of Asia and Africa. There are five hundred million people suffering from waterborne diseases for which remedies or preventive techniques exist.

5) Some seven hundred million adults throughout the world are illiterate. These include eighty per cent of the population of Africa and sixty to sixty-five per cent of the population of Asia.

6) Ninety-eight per cent of the human race now live in sovereign states. For the first time in history the nations of the human family are equal in political and juridical terms. But in economic and cultural opportunity the disparities are already vast and are growing wider. The most advanced countries are three thousand per cent more prosperous than the least advanced. The effects of science, technology and industrial progress are still largely confined to the advanced countries which contain less than a quarter of the human race. 
7) A great migration from villages to cities is going forward across the globe in conditions where urbanization increases the peril to health and social stability.

8) Some of the world's natural resources are nearing depletion, while the atmosphere and many water sources are suffering wholesale pollution.

9) There is no diminution of the arms race and little progress in evolving agreed forms of peacekeeping, even in disputes in which the Great Powers are not involved.

The "State of the World" message would not be composed entirely of these somber warnings. It would include a testimony to the healing power of science which is the central common enterprise of man. It would tell of new opportunities to fertilize soil, to harness water, to desalt the sea and irrigate the deserts, to diffuse the fruits of knowledge and to draw all men together in growing accessibility. It would portray towering feats of imagination and courage which have sent man beyond his earthly confinement into the exploration of extraplanetary vistas. It would include a new awareness of universal interests and an unexampled mingling of experiences across the frontiers of states. These consolations are real enough. But the main conclusion would be inexorable: human welfare is lagging far behind the pace of opportunity. And the reason for the lag lies in an inadequate intensity of cooperation. There are also wanton violations of rational priority. A world which spends over three hundred million dollars a day in armaments cannot find three hundred million dollars a year to maintain an organization for the defense of peace. It is easier to find budgets to invade the moon than to save the earth for urgent human needs.

The City of Man is a city with a few wealthy suburbs, vast areas of undernourishment and illiteracy-and no effective police or organs of government.

Yet governments are so preoccupied with provincial crises of limited human effect that the affairs of the human nation receive only marginal attention. The United Nations specialized agencies and conferences bring a universal vision to bear on the torment and frustrated hopes of all mankind. But they have never yet discussed them at a level of authority capable of launching cooperative and decisive action. Summit meetings still take a microscopic view of a few problems, instead of a panoramic view of the total human scene. Yet it is precisely in the concern for supra-national interests that governments have a chance of transcending their rivalries and developing trustful attitudes which 
could, in time, transform their approach to the provincial squabblesthe Vietnams and Congos of this troubled world. At the recent Convocation in New York to discuss the Papal message on "Peace on Earth," I suggested that the heads of the governments come together for a week to discuss the destiny of the planet-the population explosion, the development of resources, the spread of scientific knowledge and the structure of the evolving world community. Not all the matters which now engage their time are of greater import or dignity.

\section{The Emergence of Small Nations}

It is here that the urgency of preserving the UN framework becomes inexorable. With all its imperfections, the UN family is the only incarnation of a planetary spirit. It alone presents a vision of man in his organic unity. It does not escape into a vague universalism by ignoring the claims of nationality. A paradox of our times is that the proliferation of nation-states goes hand in hand with a search for wider forms of integration, as exemplified in the United Nations, the European Community, the Organization of American States and the Organization of African Unity. The United Nations Charter strikes a delicate balance between national identity and universal solidarity. The nation-state is still the main source of distinctive culture. In some respects all nations are like all others, and none can escape the overriding human fatalities. But those qualities which a nation holds especially to itself, its special memories and dreams, may well be its chief gift to human culture. The victories of nationalism have been won in the past two centuries against tyranny and colonialism. Those who mourn the fragmentation of the political map and long for larger political units should recall how the explosion of nationalism came about. In an area of Europe where there were once two sovereigntiesthe Austro-Hungarian and the Ottoman Empires-there are now twenty states. Where Britain and France and Belgium once held Africa under three flags there are now thirty-three. The growth of nationalism has been, in the main, a story of liberation from tyranny. National diversity can be a source of intense and positive vitality, provided that it is reconciled with the restraints and solidarities of an international order.

Even in their present form, United Nations meetings involve sovereign governments in issues outside their limited range of self-interest. To great nations the UN teaches the humility of responsible action. For small nations they offer an escape from suffocating provincialism. When Latin delegates are called upon to contemplate the Middle East, when Israel, Cyprus and Iceland adjudicate African issues, they are all 
released from excessive self-preoccupation into a world where detached inquiry enlarges understanding and deepens compassion. Each nation becomes involved in the adventure of world community. Universalism, far from being the enemy of the nation, emerges by paradox as its best friend, and quite possibly as its last one.

It is hard to imagine what the decline of international political institutions would mean for Great Power relations. The dialogue maintained in a permanent diplomatic conference has become so familiar to us for twenty years that we cannot accurately tell what its cessation would signify. It is reasonable to give the United Nations some credit for breaking up the rigid bipolar confrontation of "East" and "West." In an effort to win sympathy in the main body of disinterested opinion, even totalitarian regimes abandon their dogmatism, strike relatively moderate postures and seek alliances outside their own strict orthodoxies.

\section{The Pageant of Freedom}

There is one domain in which the existence of an international tribunal has visibly helped to transform our generation's life. The fifty-one member states which founded the United Nations in 1945 have now grown to one hundred fourteen. The original membership roll comprised twenty Latin American, twelve European and three African sovereignties. This could hardly be described as an accurate or egalitarian picture of the human map. Today the community of sovereign African States numbers thirty-three. All but a fraction of the two hundred million Africans have been freed from colonial tutelage. In Asia the process of emancipation is almost complete.

The remarkable thing is that much of this transition has been pacific. In former times national movements might cultivate, in Jefferson's words, "a decent respect for the opinion of mankind." But it was chiefly by inculcating a decent respect for their capacity to make violent trouble that they won and kept their freedom. Today the liberty of nations is a matter of birthright, not of conquest. However strongly the colonial powers chafed at the nagging persistence of the United Nations, they have never been immune to its strong bias for orderly emancipation. No colonial problem has ever been submitted to UN inquiry or judgment without a pattern of national independence emerging within a few years. And when the new state, often small and desperately poor, comes out into the light of freedom, it is its flag in the United Nations, above all else, which symbolizes and excites its sense of identity. 


\section{Limitations of the Multilateral Approach}

The mobility of the United Nations idea should not blind us to defects in the United Nations practice. After twenty years of intensive experience, three conclusions emerge.

First, there is a tendency to overestimate the value of public parliamentary techniques and to underestimate the need for bilateral limited negotiation.

Second, there is too little regard for constitutional precision. Arbitrary majority decisions are disturbing the delicate constitutional balance established by the Charter. There is also a lack of procedural versatility.

Third, the United Nations overestimates its capacity to solve political and security problems and underestimates its opportunity to control and stimulate economic and social development.

Parliamentary procedure with the participation of many states encourages bargains and compacts which sometimes destroy relevance. A nation which seeks a result in one conflict pursues its cause by committing its attitude irrelevantly in another. If two countries have a dispute on a matter not involving Israel, they tend to make speeches against Israel, designed exclusively to enlist the numerous Arab bloc on their own behalf. Thus, the tensions of one conflict communicate themselves, under the compulsions of parliamentary bargaining, to another. Does a statesman have a vast ambition to become a Chairman of a committee or President of the General Assembly? If so, he may be tempted not to examine international problems on their merits lest he incur the displeasure of large voting blocs. Thus, the relevant discussion of problems is disrupted and fragmented. Reciprocal bargaining obscures the specific context of each dispute and inhibits lucid and specialized discussion.

In the parliamentary procedure, what men seek is not a settlement but a successful vote. The majority principle is, of course, a basic democratic concept. But the majority in a parliamentary democracy is not an end in itself; it is a part of a whole system of devices for peaceful change. In the United Nations the majority principle is not inhibited by any of the restraints which accompany it within a national democracy. The weakness of majority rule in the United Nations is also illustrated by the disparity in the real strength of voting states. According to our Charter, Israel in the General Assembly equals the United States; Luxembourg equals the Soviet Union; Malta equals Great Britain. Yet we know that these formalized equalities do not 
reflect corresponding equalities of power or responsibility. It is possible, therefore, to envisage two-thirds of the General Assembly being composed of states which constitute ten per cent of humanity and which contribute five per cent of the budget.

The gravity of this development increases when the majority moves to remove the constitutional barriers to its own arbitrary will. There has recently been an erosion of constitutional integrity. For the first time, contrary to Charter provisions, decisions on substantive issues were taken in 1965 by a bare majority. Thus a majority of votes which might be a minority of mankind can commit the world community through violation of a compact. The United Nations needs a rigid and austere devotion to its written Charter, equal to that rigid, austere respect which the best democracies give to their constitutional documents. In recent weeks we have seen another example of pragmatic and arbitrary will setting itself against legal integrity. We had in the Viet Nam dispute in the Security Council the extraordinary spectacle of a member state being refused access for debate on a war. Nobody challenges the right of members of the Security Council to oppose the United States position in Viet Nam on its substance. But to bar the door to a discussion, implying that there is no automatic access for a member state desiring to expound its case, is surely to illustrate a collapse of the basic logic of the Charter.

In addition to constitutional disintegration; in addition to the violation of the two-thirds majority rule; in addition to the withholding of unreserved access to the bar of international judgment; in addition to excessive emphasis on publicity; in addition to the irrelevancies inherent in multilateral parliamentary bargains-there are other defects which have emerged in two decades of practice which are not inherent in the United Nations system itself.

I have quoted Hammarskjold's belief that there is too much emphasis by the United Nations on the technique of public debate and too little on negotiations. There is nothing in the Charter which compels the United Nations to regard the public debate as its sole technique. The Charter emphasizes the general role of UN headquarters as a center for the harmonization of policies. Yet there is no effective committee practice in which complex issues can be discussed, not in their sweeping generality but in their intricate detail. The difference between a Plenary session at the United Nations and a committee of United Nations is as follows: the Plenary session consists of one hundred fifteen sovereign states whose delegates speak standing up at the podium; a "committee" consists of the same one hundred fifteen sovereign states who speak seated at the table. This hardly expresses 
versatility of diplomatic technique. It is presumably believed that it is only when standing up that men can attain a full rhetorical frenzy, and when sitting down they can neither strut nor gesticulate. I must say that this is an inhibition which many statesmen have managed to overcome. It should surely be possible to submit issues to groups not of one hundred fifteen but of twenty or twenty-five. It is not necessary for every state to examine each political dispute on the agenda in committee stage. It should be possible for the full body to be divided into committees of twenty-five which deal selectively in closed committee with specific problems. The committee conclusions would, in any case, be brought for discussion and ratification in the Plenary sessions. In 'other words, it seems to me that even without Charter revision, and within the framework of its present procedural capacity, the United Nations could reform and rationalize its procedures.

Another weakness is the unlimited agenda. At its last session, the General Assembly considered some one hundred twenty items, of which most had been discussed at the previous sessions and no doubt will be discussed at the session to come. It seems to me that access to the agenda could be made rather more selective, except in cases of armed conflict in which it should be unconditional. What is the use of regurgitating in 1966 the precise debate that took place on a certain subject in 1965 unless in the interval there has developed some fragile but visible symptom that a renewed discussion would be fruitful? I have detected several cases in which delegates of Powers, great and small, have recited in one year the precise utterance with which they sought to electrify the world two years before. (There are few who have sufficient audacity to repeat the speech which they made only one year ago, since human memory cannot be relied on even in its weakness.) Repetitiveness of speeches and of resolutions, and unlimited debate in the name of sovereignty, are facets of United Nations life which have diminished the dignity of the international discourse. In 1965 the space devoted by the world press to United Nations discussions was disquietingly less than in 1960 and in 1955. Thus, as the years go on, procedural conservatism and the lack of any instinct for innovation are beginning to reduce the public resonance which used to be one of the United Nations' main assets.

The first item for discussion at a future session of the United Nations should be the United Nations itself. There is need for a selfcritical analysis of principles and procedures in the light of twenty years of crowded and turbulent experience.

A more recent development has been the growing power of blocs. The individual member state scarcely has an existence outside of a 
regional bloc. States which have a convinced view on a certain subject nevertheless allow their view to be transcended in order that a bloc might vote as a whole. Now, why should a bloc vote as a whole? Where is the intellectual or spiritual or historic logic which argues in favor of such unanimity? Why should twenty-one Latin American states, or thirty-three African states, be called upon automatically to share the same views on an international issue? The variety of interests, of geopolitical conditions and of cultural traditions should express itself in a fruitful diversity. Why should Asian states, with their differences of geographical and economic conditions, be expected to vote together in the name of a semantic fiction known as "continental solidarity"? Perhaps I speak here objectively, since I represent one of the few states which is not part of any bloc. I am told in Washington that the United States has a similar solitude. You will, I think, agree that this solitude is mitigated in your case by other elements of strength which are lacking in ours. But surely the concept of sovereign equality of states includes the possibility that each one has a sovereign judgment. Now that individual states have been liberated from external tutelage, they need to be liberated from the choking effects of excessive regional solidarity.

I have suggested that there is a tendency in the United Nations to overestimate what it can do in political conflicts and to underestimate its opportunity in the field of accelerated development. The United Nations, as a supra-national institution, is ideally suited to consider human affairs on a planetary scale. But its agenda is mostly made up of national disputes. It is significant that the First Committee is the committee in which insoluble political conflicts are discussed, while the Committee in which soluble problems of human society are treated are the Second and Third, and so on up to the Sixth Committee which is, significantly, the committee on law. The question arises whether a due sense of priority informs the international forum. Ministers for Foreign Affairs and heads of delegations spend most of their time in the Political Committees. They seldom make the kind of apparition which would probably startle the members of the more lowly committees which deal with social affairs, economic progress, national liberation and the formulation of international law.

\section{The Need for Innovation}

These criticisms of multilateral diplomacy are offered in sympathy, not in antagonism. Summitry, publicity and parliamentarism must not be allowed to monopolize the international discourse, even though their place within it may be irrevocably dominant. The new techniques 
should coexist with the reticence and intimacy of the classical diplomacy in an atmosphere conducive to innovation.

Tragedy lies not in what men suffer but in what they miss. The opportunity of twentieth century life mocks the reality of an age overclouded by peril and fear. There is, for the first time, the opportunity to establish a universal human community.

Social history reveals the constant enlargement of the idea of community-from family to tribe, from tribe to village, from village to city-state and from city to nation. In each case there was doubt whether the larger units would ever command the intimate and simple devotion which had been enjoyed by the smaller. Yet in each case the smaller and the larger loyalty continue to coexist. Similarly, there is no chance that a world society will supersede the deep-rooted impulse of national sentiment. Nations will have to live their lives on two levels: on the intimate level of national distinctiveness and on the broader level of universal solidarity. Much of diplomacy today is a holding action. It aims to avoid explosion until such time as the unifying processes of history take all mankind into its embrace. Modern statesmen must act in a double role: as spokesmen of their particular national interests and, at the same time, as representatives of the wider human cause. In this situation they will be no different from parliamentary representatives who combine a particular local responsibility with a broader national view. If the United Nations has not fulfilled its hopes it is largely because the immediate parochial concerns of nations have predominated too strongly against universal problems which appear to be "long term" and lacking in urgency, but which will ultimately determine humanity's central interests.

The academic movement would do well to investigate why the expansion of community, having gone through so many successful phases, has been blocked at the point of ultimate transition-from the state to the world society.

In the lofty words of Teilhard de Chardin:

Everything that formerly made for war now makes for peace. Pressed against one another by the increase in their numbers and relationships, forced together by the growth of a common travail, the men of the future will in some sort form a single consciousness.

This "single consciousness" is the central purpose of modern statecraft. If we cannot yet touch it with our hands, let us not lose it from our yision, 